\title{
Penerapan User Interface Definition Language Pada User interface Management System
}

\author{
Rifqi Cahya Prasetya ${ }^{1, *}$, Zahrul Naufaldi ${ }^{2}$, Muhammad Syafiq Rohman Noor ${ }^{3}$, Muhammad Ainul \\ Yaqin $^{4}$ \\ Teknik Informatika, Universitas Islam Negeri Maulana Malik Ibrahim, Indonesia \\ 118650107@student.uin-malang.ac.id, ${ }^{2} 18650108 @$ student.uin-malang.ac.id, ${ }^{3} 18560120 @$ student.uin-malang.ac.id, \\ 4yaqinov@ti.uin-malang.ac.id \\ * corresponding author
}

INFO ARTIKEL

Sejarah Artikel

Diterima: 20 Desember 2019

Direvisi: 17 Januari 2020

Diterbitkan: 30 Agustus 2020

Kata Kunci

User interface

Definition language

Management system

\section{ABSTRAK}

Kompleksitas Penelitian ini bertujuan untuk mengevaluasi bagaimana penerapan User interface Definition Language (UIDL) terhadap User interface Management System (UIMS). Hasil penelitian ini berupa User interface definition Language terhadap User interface Management System yang bisa dimanfaatkan untuk sistem kontrol serta sistem monitoring bel rumah klaster secara manual maupun secara otomatis menggunakan sensor. User interface tersebut sistem komunikasinya memanfaatkan internet dan OpenHAB. Bel dapat ON/OFF secara otomatis sesuai dengan perintah dari aplikasi User interface android tersebut. Nilai terendah analisis kebergunaan adalah 4,1 terkait dengan aplikasi tombol kontrol bel dapat diklik dengan mudah dan tertinggi 4,70 terkait dengan bahasanya mudah dipahami. Sedangkan rata-rata kebergunaannya 4,59. Dengan hasil tersebut maka penerapan User interface Definition Language terhadap User interface Management System dapat dengan mudah digunakan dan dipahami oleh user.

\section{PENDAHULUAN}

Teknologi sangat berperan dalam menyebarkan informasi secara cepat dan aktual. Informasi menjadi kebutuhan yang sangat penting bagi semua kalangan baik itu pribadi, komunitas, masyarakat, swasta maupun pemerintah. Berkaitan dengan informasi, semua lembaga dalam perkembangannya memerlukan sistem informasi agar dapat memaksimalkan berbagai informasi yang ada untuk lebih mudah dan secara efektif dapat di akses oleh semua orang [1]. Teknologi informasi saat ini menjadi bagian yang tidak terpisahkan dan terintegrasi dengan tujuan organisasi atau lembaga. Bagaimana teknologi informasi diaplikasikan dalam suatu lembaga sehingga akan mempengaruhi beberapa hal yang menunjang proses dalam lembaga tersebut [2]. Pengaruh yang bisa ditimbulkan dari sebuah sistem informasi seperti pencapaian visi, misi maupun berbagai hal yang berkaitan tentang strategis pengembangan lembaga tersebut. Semakin meluasnya perkembangan teknologi di bidang aplikasi mobile terutama aplikasi yang menerapkan sistem on demand, ditambah lagi tren masyarakat sekarang yang lebih sering menggunakan smartphone dan internet, semakin membuat para pengusaha, startup company, hingga perusahaan besar beralih memanfaatkan hal tersebut untuk membuat ide-ide bisnis baru [3]. Saat ini sistem informasi akademik sudah merupakan hal yang sangat umum dalam setiap perguruan tinggi. Pentingnya sebuah sistem informasi akademik terutama adalah memberikan kemudahan kepada pengguna untuk mendapatkan informasi. Dalam kemudahan mengakses sebuah sistem tersebut tidak terlepas dari yang namanya user interface [4]. Sistem informasi akademik memiliki user interface 
atau antarmuka yang berfungsi untuk menghubungkan pengguna dengan informasi yang dibutuhkan dari sistem itu sendiri. Sistem informasi memiliki desain interface yang berbedabeda sesuai dengan fungsi dan kebutuhan penggunanya. User interface yang bagus atau menarik adalah kemudahan pengguna dalam menggunakannya.

Selain itu, para pelaku usaha berlomba-lomba mengembangkan layanan on demand sehingga ada banyak sekali aplikasi on demand seperti Gojek, Grab, Boncengin, AyoJek, Oke Jack dan tentu masih banyak yang lainnya. Karena banyaknya aplikasi on-demand tersebut, pengguna pun semakin selektif dalam memilih aplikasi yang ditawarkan. Antarmuka aplikasi menjadi peran utama dalam menarik minat pengguna aplikasi on demand. Desain antarmuka yang sulit dimengerti bisa jadi akan ditinggalkan oleh pengguna. Oleh karena itu, tingkat kepuasan pengguna terhadap antarmuka aplikasi merupakan salah satu kunci penting keberlangsungan aplikasi on demand tersebut. Prinsip dalam membuat desain antar muka (user interface) sangat penting karena jika terlalu memusingkan, pengguna harus belajar lagi cara menggunakannya dan akan membuat mereka merasa kesulitan menggunakan sistem tersebut. Desain UI memiliki peran penting karena menjadi penghubung secara langsung antara sistem dengan penggunanya. Desain UI harus dibuat dengan benar, sebab akan membentuk persepsi para pengguna terhadap suatu perangkat lunak yang digunakan dan juga harus memperhatikan kemudahan penggunaan agar dapat diterima oleh masyarakat [1].

User interface yang bagus atau menarik adalah kemudahan pengguna dalam menggunakannya. Prinsip dalam membuat desain antar muka (user interface) sangat penting karena jika terlalu memusingkan, pengguna harus belajar lagi cara menggunakannya dan akan membuat mereka merasa kesulitan menggunakan sistem tersebut. Sebagai bagian dari pengembangan suatu sistem yang memenuhi standart HCI, evaluasi pada kemudahan penggunaan (usability) harus dilakukan [5]. Usability sebagai suatu pengalaman pengguna dalam berinteraksi dengan aplikasi atau suatu situs website sampai pengguna dapat mengoperasikannya dengan mudah dan cepat [6]. Ada beberapa metode yang pernah digunakan untuk mengevaluasi user interface seperti Technology Acceptance Model (TAM), system Usability scale, GOMS, terdapat pula metode evaluasi user interface lain yang dapat mengetahui tingkat user interface pada sebuah sistem yaitu dengan metode User Centered Systems Design. Desain UI memiliki peran penting bagi kesuksesan sebuah aplikasi. Jika pengguna merasa UI yang dibuat tidak menarik, sulit dimengerti, dan dapat menyebabkan kebosanan, akibat yang dapat muncul adalah kegagalan pada sebuah aplikasi.

Teknologi informasi memberikan media baru untuk menyebarkan informasi, yaitu media digital. Banyak institusi pendidikan di Indonesia sudah menggunakan media digital untuk menunjang pembelajaran, seperti penggunaan perpustakan digital. Perpustakaan digital tidak akan terlepas dari platform interaksi manusia dengan computer. Jika kita melihat "manusia" sebagai individu atau sekelompok orang yang menggunakan komputer untuk membantu menyelesaikan tugasnya, maka faktor keberhasilan interaksi atau suksesnya sistem terdistribusi perlu diperhatikan. Salah satu keberhasilan interaksi ini dapat dilihat dari kemampuan perangkat lunak (software) dalam membantu menyelesaikan tugas user [10] dan end user akan berinterkasi dengan sistem melalui interface yang dibuat, sehingga keberhasilan perpustakaan digital selain dinilai dari isinya juga dinilai dari interface nya.

Ada beberapa metode yang pernah digunakan untuk mengevaluasi user interface seperti Technology Acceptance Model (TAM), system usability scale, GOMS, terdapat pula metode evaluasi user interface lain yang dapat mengetahui tingkat user interface pada sebuah sistem yaitu dengan metode User Centered Systems Design [5][6]. Dalam metode User Centered Systems Design ini, evaluasi sistem terpusat pada interface menurut cara pandang user. User merupakan object yang penting didalam pengembangan dan pembangunan sistem yang baik. Kemudahan penggunaan (usability) merupakan isu yang krusial dalam HCI, karena hal 
itu menjadi aspek penting untuk menilai kualitas dari antarmuka (interface) pengguna [7]. Berdasarkan latar belakang tersebut, peneliti ingin menguji tentang penerapan user interface definition language pada user interface management system. Dalam hal ini,. Keunggulan penelitian yang digunakan saat ini dengan penelitian sebelumnya adalah (1)Penelitian ini menerapkan perancangan berbasis arsitektur user interface, (2) Penerapannya menggunakan rumah-rumah tipe klaster yang diharapkan hasil penelitiannya ini dapat diterapkan dan dimanfaatkan sebaik-baiknya oleh masyarakat khususnya penghuni rumah klaster.

\section{METODE}

\section{Perlengkapan Perangkat Keras}

Untuk merancang serta menerapkan sistem ini dibuat dari beberapa perangkat keras diantaranya:

a. Kabel Serial digunakan untuk komunikasi serial

b. Raspberri Pi digunakan sebagai server gateway.

c. Arduino Uno Rev 3 digunakan sebagai mikrokontroller atau pusat pengendalian sistem

d. Sensor Cahaya digunakan untuk sistem otomatisasi rumah terkait dengan pencahayaan

e. Sensor Suhu digunakan untuk sistem otomatisasi rumah terkait dengan suhu

f. Sensor Kelembaban digunakan untuk sistem otomatisasi rumah terkait dengan kelembaban

\section{Perlengkapan Perangkat Lunak}

Perangkat lunak untuk merancang serta menerapkan sistem ini terdiri dari:

a. Bahasa Pemrograman Android

b. Apache

c. MySQL

d. OS Raspbain

e. Notepad ++

f. ARDUINO_IDE

\section{Langkah-Langkah Penelitian}

Langkah penelitian yang dilakukan diawali dari identifikasi masalah yaitu mengidentifikasi permasalahan penelitian. Dari identifikasi tersebut akan didapat permasalahan yang nantinya akan diselesaikan dalam penelitian. Langkah selanjutnya adalah kegiatan perancangan sistem menggunakan teori dari tinjauan pustaka dan metodologi penelitian yang seiring dengan tema penelitian. Beberapa kajian tersebut berkaitan dengan : (1)Perancangan arsitektur User interface, (2) peralatan yang dipakai dalam perancangan. Kemudian yang dilakukan adalah perancangan sistem berdasar atas masalah yang muncul pada bagian identifikasi masalah. Langkah - langkah untuk menyelesaikan penelitian ini dijelaskan pada Gambar 1. 


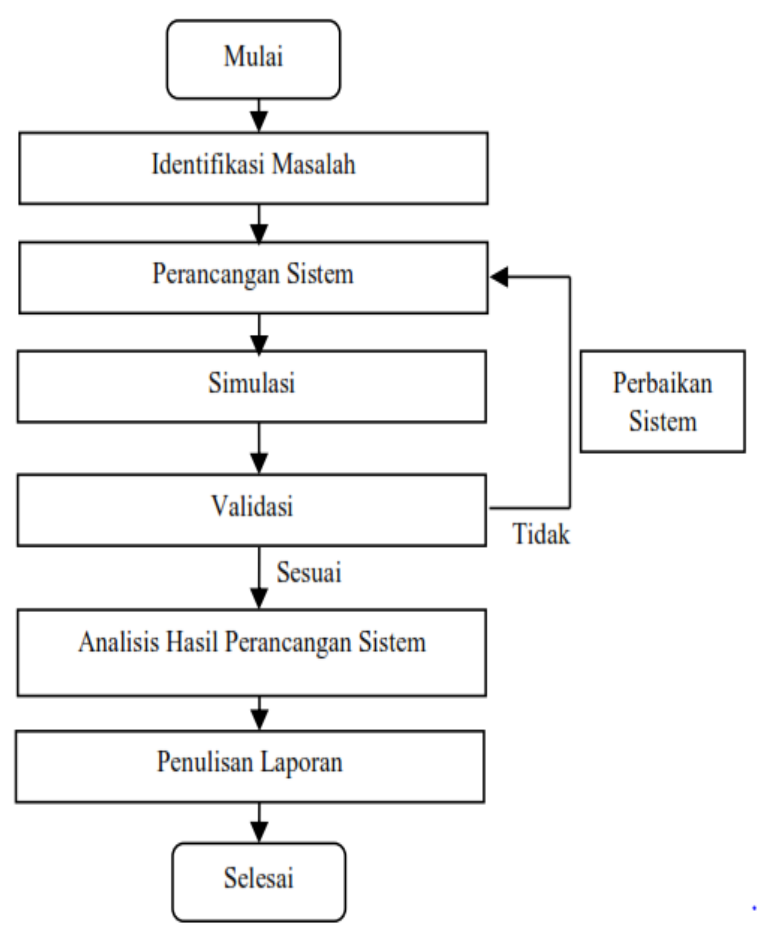

Gambar 1. Langkah Penelitian

Hasil dari kegiatan perancangan sistem ini adalah prototype User interface berbasis mobile untuk sistem otomatisasi rumah yang belum stabil serta masih perlu diuji lagi dalam rangka mengoptimalkan kinerja sistem secara keseluruhan. Selanjutnya pengujian tersebut dilakukan pada bagian-bagian tertentu yang penting. Bagian penting tersebut diantaranya sebagai berikut: (1) Sistem arsitektur User interface android, yang ke (2) Sistem manajemen monitor serta kontrol perangkat elektronik menggunakan android. Pengujian dilakukan sampai tercapai hasil yang terbaik berdasarkan pada hasil pengujian serta analisis. Pengujian serta analisis tersebut nantinya menghasilkan prototype yang lebih stabil secara keseluruhan. Selanjutnya hasil analisis serta hasil pengujian tersebut selanjutnya ditulis dalam laporan penelitian.

\section{Perancangan Sistem}

Sistem user interface definition language pada user interface management system secara bagan terlihat dalam Gambar 2. Pada gambar tersebut dijelaskan tentang flowchart perancangan sistem User interface. Pada flowchart Gambar 2 dijelaskan tentang langkah kerja sistem. Aplikasi dirancang dengan bahasa pemrograman berbasis android dengan menggunakan aplikasi android studio. Adapun langkah kerja sistem nya adalah awalnya pada saat dibuka aplikasinya langsung tertampil halaman utama aplikasi.dari halaman utama tertampil halaman untuk kontrol bel secara manual, yaitu dengan cara mengklik tombol ON/OFF pada sistem. Jika tombol bel di klik ON/OFF maka sistem akan melakukan input switch bel ke database, kemudian dari database akan dikirim melalui jaringan internet, hasilnya adalah adanya perubahan status bel yang awalnya ON menjadi OFF begitu juga sebaliknya. Sedangkan pada tampilan halaman selanjutnya yaitu halaman monitoring, pada halaman ini secara otomatis sistem mengambil data pembacaan sensor suhu, sensor kelembaban serta sensor cahaya. Hasil pembacaan sensor tersebut kemudian disimpan kedalam database. Dari database kemudian ditampilkan pada halaman monitoring. 


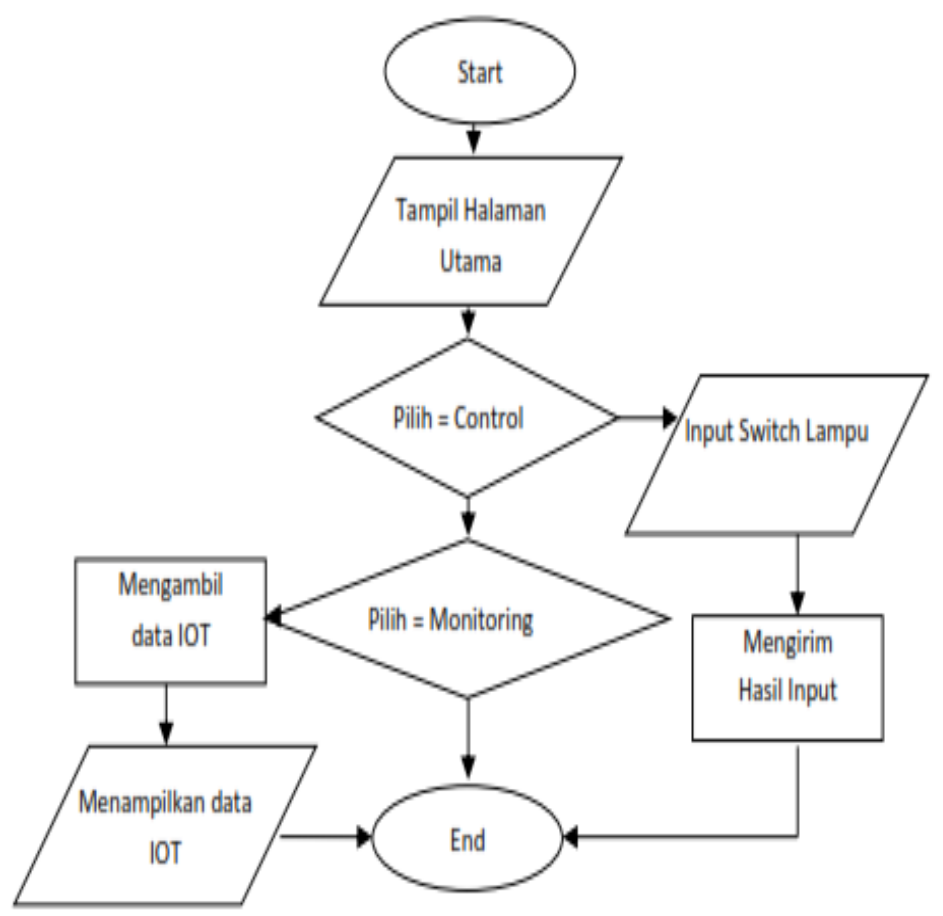

Gambar 2. Flowchart User interface

\section{HASIL DAN PEMBAHASAN}

\section{Pengujian User interface}

Pengujian ini bertujuan untuk melihat apakah sistem User interface Definition Language benar - benar bekerja dengan baik atau tidak pada User interface Management System. User interface tersebut dibuat dengan nama home klaster automation. Dalam aplikasi tersebut dibuat 2 halaman yaitu halaman control dan halaman monitor, pada halaman control terdapat 3 buah control bel diantaranya yaitu control bel 1, control bel 2 , dan control bel 3. User atau pengguna dapat mematikan dan menyalakan bel dengan cara mengklik button ON/OFF yang ada di samping kanan. Dengan cara klik tersebut maka bel dapat dikontrol secara manual jarak jauh melalui android. Saat bel 1 diklik ON maka sistem akan mengirimkan perintah ke server kemudian melalui komunikasi serial perintah tersebut disampaikan ke mikrokontroller untuk menyalakan bel 1. Begitu juga halnya untuk bel 2 dan bel 3. Tampilan halaman control bel tersebut ditunjukkan pada Gambar 3.

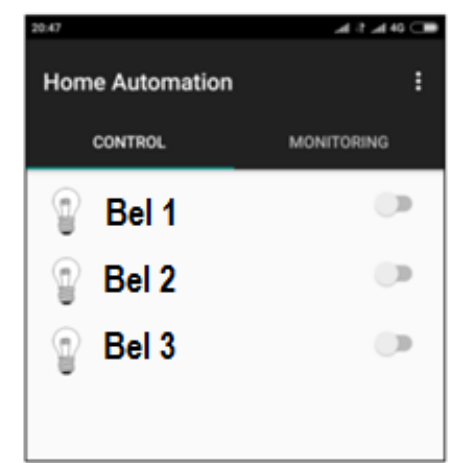

Gambar 3. Halaman Kontrol Lampu 
Selanjutnya untuk status bel apakah sedang ON / OFF dapat dilihat pada halaman tersebut, yaitu dengan berubahnya gambar bel dari abu-abu(diam) menjadi kuning(berdering). Dengan adanya status bel tersebut maka pengguna dapat memantau keadaan bel setiap saat. Adapun tampilan status bel dapat dilihat pada Gambar 4.

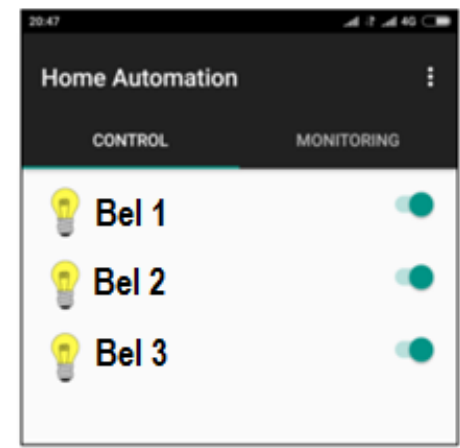

Gambar 4. Tampilan Status Bel

Sedangkan pada halaman ke dua adalah halamansistem monitoring. Terdapat 3 buah parametesensor yang ditanamkan pada sistem dan dipantausecara realtime. Diantaranya yaitu sensotemperature, sensor kelembaban, dan juga sensor cahaya. Adapun tampilan halaman monitoring dapadilihat pada Gambar 5.

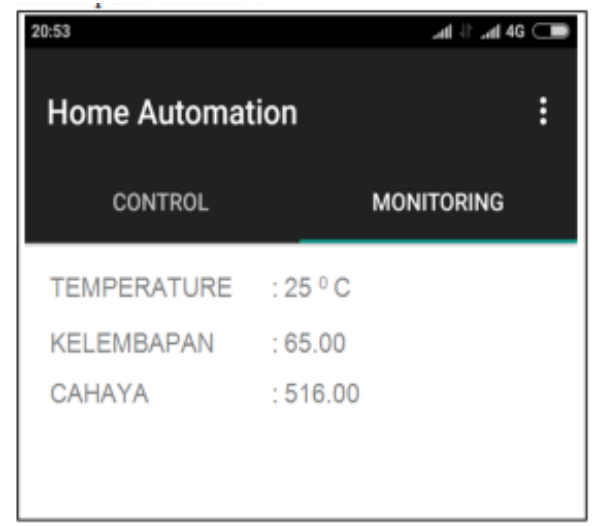

Gambar 5. Halaman monitoring

Pada halaman Gambar 5 secara realtime dapat menampilkan hasil pembacaan masingmasing sensor. Hasilnya dapat berubah-ubah sesuai dengan hasil pembacaan sensor. Data hasil pembacaan sensor secera real time dikirim ke server, kemudian disimpan kedalam database, setelah itu kemudian ditampilkan pada halaman monitoring. Data secara real time di kirim setiap 5 menit.

\section{Pengujian Kebergunaan}

Pengujian kebergunaan dilakukan dengan tujuan untuk mengetahui seberapa besar tingkat penerimaan terhadap User interface yang telah dibuat. Sehingga nantinya aplikasi tersebut dengan yakin dapat bahwa semua kebutuhan sistem telah terpenuhi dan dapat diterapkan serta dioperasikan oleh pengguna. Metode yang digunakan dalam pengujian ini adalah dengan menggunakan metode kuesioner. Kuesioner dibagi kepada 20 mahasiswa dari berbagai usia yang telah mengerti tentang aplikasi berbasis android dan telah mampu mengoperasikan aplikasi android. Pada awalanya pengguna diberi daftar tugas yang harus dilakukan terlebih dahulu terhadap User interface yang akan diuji. Adapun beberapa tugas 
yang diberikan kepada pengguna dapat dilihat pada Tabel 1 dibawah ini. Penjelasan dari masing-masing tugas tersebut adalah sebagai berikut:

Tugas 1. Membuka Aplikasi di Android Pada tugas ini pengguna diminta untuk membuka aplikasi User interface pada sistem operasi android.

Tabel 1. Daftar tugas

\begin{tabular}{|c|c|}
\hline No & Daftar Tugas \\
\hline 1 & Membuka Aplikasi di Android \\
\hline 2 & Membuka Halaman Kontrol \\
\hline 3 & Mengklik tombol On/Off di aplikasi android \\
\hline 4 & Membuka halaman monitoring \\
\hline 5 & Memantau nilai pembacaan sensor \\
\hline
\end{tabular}

Kemudian Tugas 2. Membuka Halaman Control. Pada tugas ini pengguna diminta untuk membuka halaman control, dari halaman tersebut dapat dilihat terdapat tiga buah status bel. Tugas 3. Mengklik Tombol ON/OFF lampu di aplikasi android Tugas ini adalah kelanjutan dari tugas sebelumnya yaitu pengguna diminta untuk mengklik tombol ON/OFF bel, serta melihat perubahan status lampu apakah sedang ON atau OFF. Tugas 4. Membuka Halaman Monitoring. Pada Tugas 4 ini pengguna diminta untuk membuka halaman monitoring. Tugas 5. Memantau Nilai Pembacaan Sensor. Selanjutnya pada tugas 5 ini pengguna diminta untuk memantau hasil pembacaan nilai sensor, baik sensor suhu, kelembaban, maupun sensor cahaya. Selanjutnya setelah pengguna melaksanakan tugas yang diberikan, maka pengguna diminta untuk menjawab 10 pertanyaan. Setiap pertanyaan mempunyai rentang nilai skala 5 (Skala Likert). Pengguna cukup memberikan tanda silang atau centang pada masing-masing pertanyaan. Pertanyaan tersebut dibuat dengan tujuan untuk menunjukkan tingkat kebergunaan menurut sudut pandang pengguna. Dari 20 responden yang telah menjawab pertanyaan didapat hasil seperti pada Tabel 2 dan Tabel 3 dibawah:

Tabel 2. Pertanyaan untuk responden

\begin{tabular}{|c|c|c|c|c|c|c|}
\hline \multirow{2}{*}{ No } & \multirow{2}{*}{ Pertanyaan } & \multicolumn{5}{|c|}{ Nilai Skala } \\
\hline & & 1 & 2 & 3 & 4 & 5 \\
\hline 1 & Apakah aplikasi dapat dikenali dari halaman awal? & & & & & \\
\hline 2 & Apakah aplikasi dapat dibuka dengan mudah? & & & & & \\
\hline 3 & Apakah aplikasi tombol kontrol bel dapat diklik dengan mudah? & & & & & \\
\hline 4 & Apakah informasi status bel mudah dipahami? & & & & & \\
\hline 5 & Apakah dapat mengakses setiap halaman dengan mudah? & & & & & \\
\hline 6 & Apakah huruf disetiap halaman dapat dimengerti? & & & & & \\
\hline 7 & Apakah simbol-simbol yang ada dapat dipahami dengan baik? & & & & & \\
\hline 8 & Apakah desain halaman aplikasinya mudah dipakai? & & & & & \\
\hline 9 & Apakah bahasanya mudah dipahami? & & & & & \\
\hline 10 & $\begin{array}{l}\text { Apakah menu-menu dalam aplikasi dapat diingat kembali setelah } \\
\text { keluar dari aplikasi? }\end{array}$ & & & & & \\
\hline
\end{tabular}


Tabel 3. Hasil dari responden

\begin{tabular}{|c|l|c|}
\hline No & \multicolumn{1}{|c|}{ Pertanyaan } & \\
\hline $\mathbf{1}$ & \multicolumn{1}{|c|}{ Apakah aplikasi dapat dikenali dari halaman awal? } & Nilai \\
\hline $\mathbf{2}$ & Apakah aplikasi dapat dibuka dengan mudah? & 4,8 \\
\hline $\mathbf{3}$ & Apakah aplikasi tombol kontrol bel dapat diklik dengan mudah? & 4,1 \\
\hline $\mathbf{4}$ & Apakah informasi status bel mudah dipahami? & 4,5 \\
\hline $\mathbf{5}$ & Apakah dapat mengakses setiap halaman dengan mudah? & 4,75 \\
\hline $\mathbf{6}$ & Apakah huruf disetiap halaman dapat dimengerti? & 4,5 \\
\hline $\mathbf{7}$ & Apakah simbol-simbol yang ada dapat dipahami dengan baik? & 4,4 \\
\hline $\mathbf{8}$ & Apakah desain halaman aplikasinya mudah dipakai? & 4,6 \\
\hline $\mathbf{9}$ & Apakah bahasanya mudah dipahami? & 4,9 \\
\hline & $\begin{array}{l}\text { Apakah menu-menu dalam aplikasi dapat diingat kembali setelah } \\
\mathbf{1 0}\end{array}$ & 4,7 \\
\hline
\end{tabular}

Dari hasil tabel diatas didapat bahwa, untuk pertanyaan (1). Apakah Aplikasi dapat dikenali dari halaman Awal didapat hasil rata-rata nilai 4,8. Hal ini menunjukkan bahwa aplikasi tersebut mudah dikenali dari halaman awal. Sedangkan untuk pertanyaan ke (2). Apakah aplikasi dapat dibuka dengan mudah didapat hasil 4,7. Nilai tersebut juga menunjukkan aplikasi User interface dapat dibuka dengan mudah. Selanjutnya untuk pertanyaan ke (3). Apakah aplikasi tombol kontrol bel dapat di klik dengan mudah didapat hasil 4,1 yang dapat diartikan aplikasi tersebut tombol control belnya dapat diklik dengan mudah sekali. Ke (4) untuk pertanyaan Apakah informasi status bel mudah di pahami didapat hasil 4,5. Hal tersebut menunjukkan bahwa informasi status bel dapat dipahami dengan sangat mudah. Selanjutnya pertanyaan ke (5). Yaitu Apakah dapat mengakses setiap halaman dengan mudah didapat hasil 4,75 yang menunjukkan pengguna dapat dengan mudah mengakses setiap halaman. Kemudian untuk pertanyaan ke (6). Apakah huruf yang ada disetiap halaman dapat dimengerti didapat hasil 4,5 yang menunjukkan bahwa huruf yang ada pada setiap halaman dapat dimengerti dengan mudah. Ke (7). Apakah simbolsimbol yang ada dapat dipahami dengan mudah didapat nilai 4,4 juga menunjukkan bahwa simbol - simbol yang dipakai dapat dipahami dengan mudah. Selanjutnya pada pertanyaan ke (8). Apakah desain halaman aplikasinya mudah dipakai dengan nilai 4,6 dapat diartikan bahwa desain halaman aplikasi mudah dipakai. Ke (9). Untuk pertanyaan apakah bahasanya mudah dipahami, didapat nilai 4,9 yang menunjukkan bahwa bahasa yang dipakai dalam aplikasi User interface mudah dipahami. Yang terakhir (10). Untuk pertanyaan Apakah menu-menu dalam aplikasi dapat diingat kembali setelah keluar aplikasi, didapat hasil 4,7 yang dapat diartikan bahwa menu-menu dalam aplikasi dapat diingat kembali dengan mudah setelah keluar dari aplikasi. Kemudian dari hasil yang sudah didapat tersebut dapat disimpulkan dengan membuat rata-rata hasil bahwa hasil nya adalah 4,59 yang dapat disimpulkan bahwa User interface tersebut dapat dengan mudah digunakan oleh pengguna.

\section{KESIMPULAN}

Hasil penelitian ini berupa User interface definition Language terhadap User interface Management System yang bisa dimanfaatkan untuk sistem control serta sistem monitoring bel rumah klaster secara manual maupun secara otomatis menggunakan sensor. User interface tersebut sistem komunikasinya memanfaatkan internet dan OpenHAB. Bel dapat ON/OFF secara otomatis sesuai dengan perintah dari aplikasi User interface android tersebut. Nilai terendah analisis kebergunaan adalah 4,1 terkait dengan aplikasi tombol kontrol bel dapat diklik dengan mudah dan tertinggi 4,70 terkait dengan bahasanya mudah 
dipahami. Sedangkan rata-rata kebergunaannya 4,59. Dengan hasil tersebut maka penerapan User interface Definition Language terhadap User interface Management System dapat dengan mudah digunakan dan dipahami oleh user.

\section{REFERENSI}

[1] Anggraini, Gita Listya. Analisis User Experience dan User interface pada Website Job Portal dengan Pendekatan User-Centered Design dan GOMS Analysis. Diss. Universitas Gadjah Mada, 2015.

[2] Najah, Shofiyatun, et al. "User interface (UI) Discovery Application To Measure Query Accuracy On Interface Repository." Journal Of Development Research 3.1 (2019): 1-6.

[3] Najah, Shofiyatun, et al. "Mengukur Akurasi Query Pada Interface Repository Menggunakan User interface (UI) Discovery Berbasis Software as a Service (SAAS)." Briliant: Jurnal Riset dan Konseptual 4.1 (2019): 206-214.I

[4] Yaqin, Muhammad Ainul, Riyanarto Sarno, and Abd Charis Fauzan. "Scalability measurement of business process model using business processes similarity and complexity." 2017 4th International Conference on Electrical Engineering, Computer Science and Informatics (EECSI). IEEE, 2017.

[5] Firdaus, Mgs Afriyan. "Analisis Struktur Navigasi Antaramuka Pengguna Pada Penyebaran Informasi Publik Berbasis Web (Studi Kasus Website Departemen Negara RI)." Jurnal Sistem Informasi (JSI) 1.2 (2009).

[6] Sutabri, Tata. Analisis sistem informasi. Penerbit Andi, 2012.

[7] Jacobsen, H-A., and Bernd J. Kramer. "Modeling interface definition language extensions." Proceedings 37th International Conference on Technology of Object-Oriented Languages and Systems. TOOLS-Pacific 2000. IEEE, 2000.

[8] Foley, James, et al. "The User interface Design Environment." ACM SIGCHI Bulletin 20.1 (1988): 77-78.

[9] Limbourg, Quentin, et al. "USIXML: A User interface Description Language Supporting Multiple Levels of Independence." ICWE Workshops. 2004.

[10] Fauzan, Abd Charis, et al. "Extracting common fragment based on behavioral similarity using transition adjacency relations for scalable business processes." 2017 11th International Conference on Information \& Communication Technology and System (ICTS). IEEE, 2017. 